\title{
Renal Sympathetic Denervation by Image-Guided Percutaneous Ethanol Injection - Histopathologic Characteristics, Efficacy and Safety
}

\author{
Renale Denervation durch bildgestützte perkutane periarterielle \\ Ethanol-Injektion - histopathologische Charakteristiken, \\ Wirksamkeit und Sicherheit
}

Authors

Patrick Freyhardt ${ }^{1,2}$, Patrick Haage ${ }^{3}$, Anna Walter ${ }^{4}$, Birgit Aufmesser-Freyhardt ${ }^{2}$, Rolf W. Guenther ${ }^{4}$, Florian Streitparth ${ }^{5}$

Affiliations

1 University Witten/Herdecke, Faculty of Health, School of Medicine, Witten, Germany

2 Department of Diagnostic and Interventional Radiology, HELIOS Hospital Krefeld, Krefeld, Germany

3 Department of Diagnostic and Interventional Radiology, HELIOS University Hospital Wuppertal, Wuppertal, Germany

4 Charité - Universitätsmedizin Berlin, corporate member of Freie Universität Berlin, Humboldt-Universität zu Berlin, and Berlin Institute of Health, Department of Radiology, Berlin, Germany

5 Department of Radiology, Ludwig-Maximilians-University Munich, Munich, Germany

Key words

image-guided periarterial injection, interventional

procedures, hypertension, renal denervation,

ethanol sympathicolysis, sympathetic nerves

received 19.09.2019

accepted 11.12.2019

Bibliography

DOI https://doi.org/10.1055/a-1085-2645

Published online: 28.1.2020

Fortschr Röntgenstr 2020; 192: 549-560

(c) Georg Thieme Verlag KG, Stuttgart · New York

ISSN 1438-9029

Correspondence

Dr. Patrick Freyhardt

Institut für Diagnostische und Interventionelle Radiologie, HELIOS-Klinikum Krefeld, Lutherplatz 40, 47805 Krefeld,

Germany

Tel.: ++49/2151/32 2561

patrick.freyhardt@helios-gesundheit.de

\section{ZUSAMMENFASSUNC}

Hintergrund Evaluation von Wirksamkeit und Sicherheit der chemischen renalen Denervation mittels bildgestützter periarterieller Ethanol-Injektion in Schweinen mit Schwerpunkt auf histopathologische Charakteristiken.
Material und Methoden In 16 narkotisierten Schweinen erfolgte eine 1-seitige periarterielle Ethanol-Injektion um eine Nierenarterie. Die unbehandelte Niere diente als Kontrolle. Alle Interventionen erfolgten in einem offenen MRT mit multiplanaren Echtzeit-Sequenzen zur Navigation. 10 Schweinen wurden $5 \mathrm{ml}$ (6 Tiere, Gruppe I), respektive $10 \mathrm{ml}$ (4 Tiere, Gruppe II) eines Ethanol-Carbostesin-Kontrastmittelgemisches injiziert. 6 Tiere (Gruppe III) wurden mit $10 \mathrm{ml}$ eines Ethanol-Polyacryl (2\%) -Gemisches behandelt. 4 Wochen nach der Intervention wurde bei allen Tieren eine MRT-Untersuchung mit MRA durchgeführt. Nach erfolgter Euthanasie wurden eine makroskopische und histologische Untersuchung der Nieren, der Nierenarterien sowie des angrenzenden Bindegewebes zum Nachweis induzierter Nervendegenerationen und potenzieller Nebeneffekte durchgeführt. Als Surrogatparameter für die Wirksamkeit wurde die Noradrenalin-Konzentration des Nierengewebes (RTNEC) bestimmt.

Ergebnisse In den Präparaten aller Gruppen fanden sich histologische Zeichen einer periarteriellen Nervenschädigung unterschiedlicher Ausprägung und zirkumferentieller Verteilung. Die maximale Distanz geschädigter Nerven zur Gefäßintima betrug 7,6 mm. In den Gruppen II und III zeigte sich die Nervenanzahl auf der behandelten Seite signifikant reduziert im Vergleich zur Gegenseite. Nierenarterienstenosen fanden sich bei keinem Versuchstier. In Gruppe II wiesen alle Tiere einen signifikanten RTNEC-Abfall mit einer mittleren Reduktion von $53 \%(p<0,02)$ auf der behandelten Seite auf. In den Gruppen I und III wurde keine signifikante Veränderung der RTNEC beobachtet.

Schlussfolgerung Die bildgestützte, perkutane periarterielle Ethanol-Injektion zur renalen Denervation erwies sich als wirksam und sicher. Die beobachteten Variationen in der Ausprägung der induzierten histopathologischen Veränderungen unterstreichen die Notwendigkeit einer Optimierung der Technik mit dem Ziel eines maximalen Behandlungseffekts im Menschen.

\section{Kernaussagen:}

- Die renale Denervation durch perkutane periarterielle Ethanolinjektion ist eine effektive und potenziell sichere Prozedur.

- Der perkutane Zugang hat weniger anatomische und prozedurale Limitationen als endovaskuläre Verfahren. 
- Die erzielbare Tiefe der Nervenschädigung ist größer als bei gängigen RFA-Elektroden.

- Die Wirksamkeit ist abhängig von Menge, Konzentration, Viskosität und periarterieller Verteilung des Ethanolgemischs.

- Eine optimale Balance zwischen diesen Parametern ist entscheidend für eine maximale Effektivität bei minimalem Risiko.

\section{ABSTRACT}

Purpose Evaluation of the efficacy and safety of chemical renal denervation by image-guided periarterial ethanol injection in pigs with emphasis on histopathological characteristics.

Materials and Methods Unilateral renal periarterial ethanol injection under general anesthesia was performed in 16 animals with the contralateral kidney serving as the control. All interventions were performed in an open MRI system under real-time multiplanar guidance. In 10 pigs an ethanol-carbostesin contrast agent mixture was injected with amounts of $5 \mathrm{ml}$ ( 6 animals, group I) and $10 \mathrm{ml}$ (4 animals, group II). 6 pigs (group III) were treated with $10 \mathrm{ml}$ of an ethanol-polyacrylic (2\%) mixture. Four weeks after treatment, all animals underwent MRI including MRA. After euthanasia, macroscopic and histologic examination of the kidneys, renal arteries and periarterial tissue was performed to assess nerve injury and potential side effects. Furthermore, the norepinephrine concentration (RTNEC) in the renal tissue was determined as a surrogate parameter of efficacy.

Results Histologic signs of nerval degeneration with various degrees of severity and circumferential distribution were found in all groups. Injury depths ranged up to $7.6 \mathrm{~mm}$. In groups II and III the nerve count was significantly lower on the treated side. Renal artery stenosis was not observed in any pig. In all pigs of group II treatment resulted in neural degeneration with a mean RTNEC reduction of $53 \%(p<0.02)$. In groups I and III significant changes in RTNEC were not observed.

Conclusion Image-guided percutaneous periarterial ethanol injection was efficient and safe for renal denervation. The detected variations in histologic outcome underlined the importance of the preclinical optimization of the technique in order to maximize treatment effects in humans.

\section{Key Points:}

- Renal denervation by percutaneous periarterial ethanol injection is an effective and potentially safe procedure.

- The percutaneous approach is less prone to anatomical and procedural limitations compared to catheter-based procedures.

- The achievable nerve injury depth lies beyond those of current RFA-probes.

- Efficacy depends on amount, concentration, viscosity and periarterial distribution of the ethanol-mixture.

- Establishing an optimal balance between these parameters is mandatory for a maximum treatment effect at minimum risk for sensitive adjacent structures.

\section{Citation Format}

- Freyhardt P, Haage P, Walter A et al. Renal Sympathetic Denervation by Image-Guided Percutaneous Ethanol Injection - Histopathologic Characteristics, Efficacy and Safety. Fortschr Röntgenstr 2020; 192: 549-560

\section{Introduction}

Ten years after the first publication by Krum et al. describing renal denervation (RDN) by catheter-based radiofrequency ablation (RFA) for the treatment of treatment-resistant hypertension, the topic continues to be a contentious issue [1]. While the latest published preliminary and final results of randomized-controlled studies (RADIANCE-HTN-SOLO, SPYRAL-OFF-MED, SPYRAL-ON-MED) are promising, limitations still remain [2-4]. First, even the use of RFA catheters of the $2^{\text {nd }}$ generation may be hindered by anatomical conditions [5]; second, potentially associated complications such as arterial stenosis and dissection may occur [6]; and third, incomplete denervation may occur due to limited maximum injury depths of available RFA catheter systems. As a result, treatment success may be impeded with at least considerable heterogeneity in individual responses and a relevant portion of patients who may not respond sufficiently to RDN [7].

Chemical RDN (CRDN) with perivascular application of neurolytic substances has been the subject of several studies in the recent past [8-10]. In 2013 and 2014, Streitparth et al. were the first to report successful treatment of therapy-resistant hypertension with cRDN after image-guided percutaneous periarterial ethanol injection in an in-vivo porcine model and first-in-human treatment [11]. This was endorsed by Ricke et al. in a Phase II Pilot Trial with a significant reduction of both office and 24-hour systolic blood pressure [12].

Yet, all of these studies lack a detailed histological analysis. Therefore, the aim of this article was to provide detailed information about the efficacy and safety of ethanol-mediated percutaneous cRDN with an emphasis on the histological effects on nerves and surrounding structures. Consequently, this might help to optimize treatment and intervention protocols of future applications and clinical studies.

\section{Materials and Methods}

\section{Animal study}

In this study 16 domestic pigs with a mean body weight of $26.5 \pm$ $2.7 \mathrm{~kg}$ prior to intervention and $30.8 \pm 5.2 \mathrm{~kg}(n=15)$ before euthanasia were treated. The porcine model was chosen because anatomic conditions such as arterial diameter and morphology are similar to that of humans [13]. The study was approved by the local Animal Research Committee. 


\section{Interventional procedure}

All cRDN interventions were performed with MRI guidance in a 1.0T-open MRI unit (Panorama HFO, Philips Medical Systems, Netherlands) with the animals under general anesthesia and continuous monitoring of vital signs. The technique has been described in detail elsewhere [8]. In brief: in all animals the optimal entry point was determined using T1 / T2-weighted TSE sequences. Then, a 20G Chiba needle (Cook Medical) was advanced to the ostium of the left renal artery.

After aspiration to exclude intravascular needle placement, $1 \mathrm{ml}$ of a bupivacaine-gadolinium-based contrast agent (CA) solution (Carbostesin 0.5\%, Astra Zeneca, Wedel, Germany; Gadovist, Bayer Healthcare, Berlin, Germany) was injected periarterially. Hereafter, a mixture of ethanol (95\%, B. Braun, Melsungen, Germany) and Gadovist (ethanol-carbostesin-to-Gadovist ratio of 600:1) was injected. The first 6 pigs were treated with $5 \mathrm{ml}$ each (group I), the next 4 animals with $10 \mathrm{ml}$ each using the same ethanol-contrast agent ratio (group II).

Since extensive tissue distribution of the injectant due to the good solubility of ethanol may lead to complications, e. g. ureter fibrosis with consecutive hydronephrosis, polyacrylic was added to the mixture in pigs 11-16 in order to achieve higher viscosity of the injectant for better adherence to the renal artery. Pigs 11, 12 and 14 were treated with $10 \mathrm{ml}$ of an ethanol-polyacrylic (2\%) mixture (ratio $70 \%: 30 \%$ ) and two more animals with an ethanolpolyacrylic ratio of $80 \%: 20 \%$ (group III). One animal (pig 13) died due to cardiac arrest on the way to the angiography suite prior to intervention and was therefore excluded from group III.

\section{Technical outcome}

Periarterial injectant distribution was assessed by acquisition of a T2w SPIR (Spectral Presaturation with Inversion Recovery) TSE plus a T1w TSE sequence 15-20 minutes after injection and rated on a four-point Likert scale ( 3 = excellent, 2 = sufficient, 1 = insufficient, 0 = renal artery missed). In animals no. 7-16, MR angiography as well as MR urography were acquired on the day of euthanasia. The time points for euthanasia ranged from 2 hours to 42 days post intervention ( $\triangleright$ Table 1 ).

\section{Histopathological analysis}

Histopathologic assessment was conducted according to the suggestions of Sakakura et al. [14] and included H\&E stains for the identification of ethanol-induced renovascular, nerval and soft-tissue damage. Furthermore, EvG stains for the detection of periand endoneural fibrosis and immunostaining against S100-protein as a marker for Schwann cells were utilized. After 3-4 mm transverse sectioning of the renal artery itself and its periarterial stroma, the tissue samples were sectioned into $5 \mu \mathrm{m}$ slices and stained. Analysis of all samples was performed by an experienced, independent neuropathologist, looking for signs of nerve degeneration and alterations to the renal artery and periarterial stroma. Each renal artery was divided into three segments (proximal, medial, distal) and the periarterial space was divided into four quadrants. The severity of nerve injury was rated on a 5-point Likert scale (grade 0: no injury, grade 1: minimal injury, grade
2: mild injury, grade 3: moderate injury; grade 4: severe injury). The distances of injured nerves from the arterial lumen were measured. Since histopathologic visualization of a completely destroyed nerve fascicle is very difficult, treatment effect and successful denervation were assessed by comprehensive analysis of the nerve density between the treated and untreated side. For histologic assessment of renovascular morphology, all specimens were searched for endothelial loss, thrombus formation and medial damage. Possible injury to the periarterial tissues was also rated on a 4-point Likert scale (0: no damage, 1: minimal damage, 2: mild damage, 3: moderate damage, 4: severe damage).

\section{Noradrenaline and blood pressure measurements (RTNEC)}

Renal tissue norepinephrine concentration (RTNEC in $\mathrm{ng} / \mathrm{g}$ parenchyma) of both kidneys was determined as the second marker of efficacy. Therefore, both kidneys were homogenized in $0.1 \%$ formic acid and centrifuged immediately after explantation. RTNEC measurement was then performed by high-performance liquid chromatography (HPLC) according to Bauch et al. [15].

Furthermore, blood pressure $(\mathrm{BP} / \mathrm{mmHg})$ was measured in all animals before and immediately after intervention and prior to euthanasia in 9 animals. All given BP values are means of three consecutive measurements.

Statistical analysis included the Kolmogorov-Smirnov and Shapiro-Wilks test and, according to data distribution, a paired t-test or Wilcoxon test for testing significance (SPSS statistics, Version 21; IBM Corp., Armonk, NY, USA); $>0.05$ was considered statistically significant.

\section{Results}

\section{Technical outcome}

Ethanol injection was feasible in all animals with an optimal injectant distribution (score 3 ) in 10 of 15 pigs (67\%) ( $\mathbf{F i g . ~ 1 a , ~ b ) . ~}$ Injectant distribution was sufficient (score 2 ) in 3 pigs (20\%) and insufficient in 2 animals (13\%). In one animal, the applied ethanol missed the renal artery entirely (score 0 ). The mean distribution score was $2.53 \pm 0.74$. Compared to groups I and II, the distribution of injectant to the periarterial and perirenal space was less widespread in the ethanol-polyacrylic group as the more viscous injectant deposited closer to the renal artery. This was rated as technically highly successful (grade 3 ) in $93 \%$ (mean 2.8) $(\triangleright$ Fig. 1c, d).

\section{Safety/complications and adverse events}

All animals were in good clinical condition throughout the whole observation period. Adverse events (AEs) were observed in 4 pigs. 3 animals showed ethanol-associated complications: in pigs 4 and 9 , slight superficial sclerosis of the renal capsule without involvement of the deeper tissue layers was found which was rated as a minor AE. In pig 7 (Group II) hydronephrosis with subsequent necrosis and interstitial fibrosis of the renal tissue on the treated side due to ureter stricture was found during autopsy at day 31 post-in- 


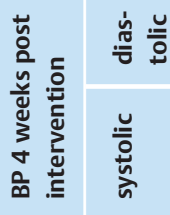

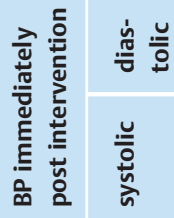

产产产

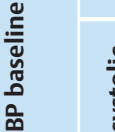

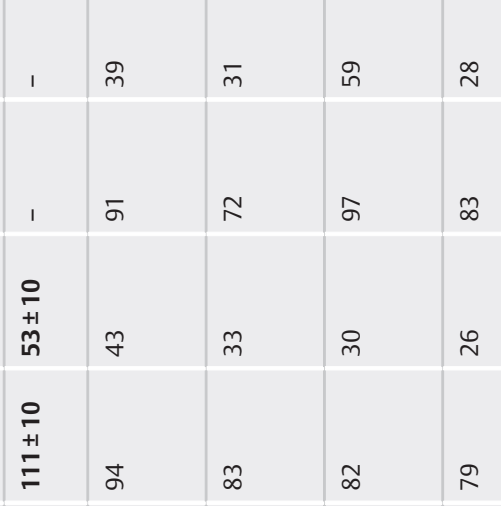

垈

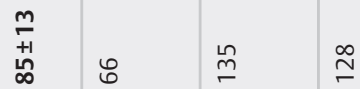

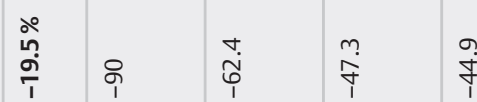

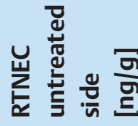

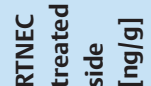

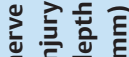

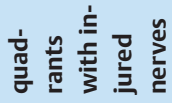

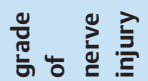

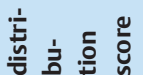

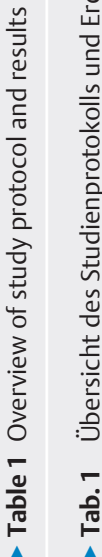

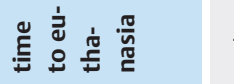

䓂

㐫

言要

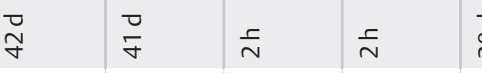

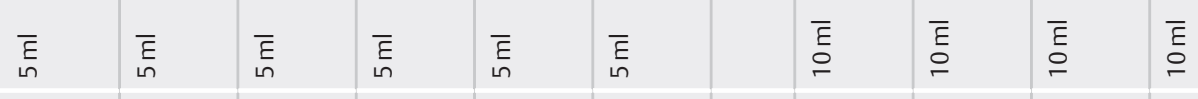

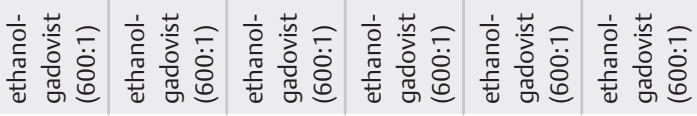

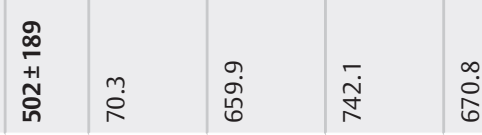

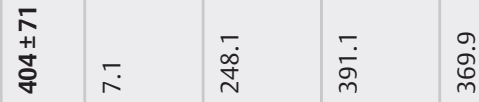

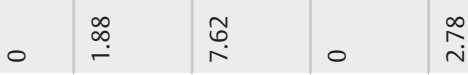

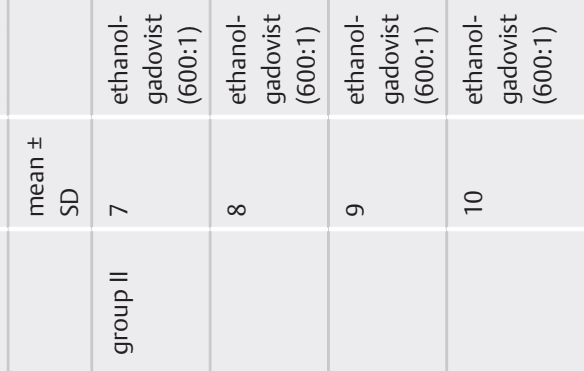




\begin{tabular}{|c|c|c|c|c|c|c|c|c|c|}
\hline \multirow{2}{*}{ 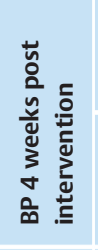 } & $\stackrel{\dot{m}}{\frac{m}{5}}$ & $\begin{array}{l}\frac{\sigma}{2} \\
+1 \\
\text { Oे }\end{array}$ & $\forall$ & 号 & $\stackrel{\infty}{m}$ & $\stackrel{\llcorner}{\sim}$ & $N$ & $\begin{array}{l}\text { f } \\
+1 \\
\text { in }\end{array}$ & \multirow{6}{*}{ 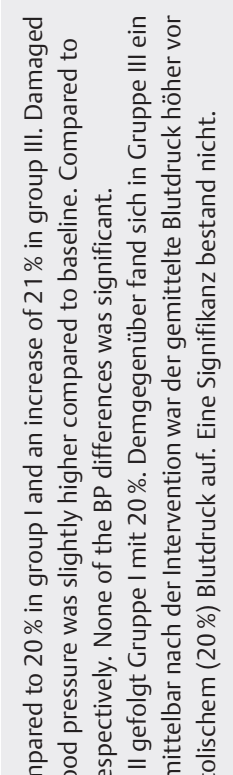 } \\
\hline & $\begin{array}{l}\frac{u}{\bar{a}} \\
\frac{\hat{n}}{n}\end{array}$ & $\begin{array}{l}\bar{\Gamma} \\
+1 \\
0 \\
0\end{array}$ & $\stackrel{\varrho}{=}$ & à & n̆ & $\stackrel{\operatorname{Ln}}{\wedge}$ & $\stackrel{m}{m}$ & 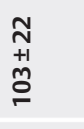 & \\
\hline \multirow{2}{*}{ 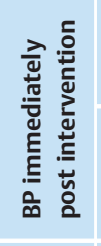 } & 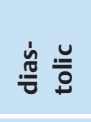 & $\stackrel{N}{+1}$ & $\approx$ & 亡ั & in & レั & $\stackrel{\infty}{\forall}$ & $\underset{\substack{m \\
+1 \\
\text { in }}}{\text { in }}$ & \\
\hline & 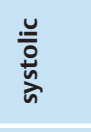 & $\begin{array}{l}1 \\
+1 \\
\text { 方 } \\
\infty\end{array}$ & $\hat{m}$ & $\stackrel{\varrho}{=}$ & $\stackrel{ }{=}$ & $\stackrel{\infty}{\wedge}$ & $\stackrel{\infty}{ \pm}$ & 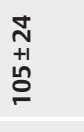 & \\
\hline \multirow[b]{2}{*}{ के } & 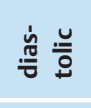 & 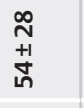 & ஜீ & 亡n & $\hat{m}$ & $\stackrel{\llcorner}{\sim}$ & $\stackrel{\llcorner}{\sim}$ & $\begin{array}{l}\stackrel{n}{2} \\
+1 \\
\stackrel{m}{m}\end{array}$ & \\
\hline & 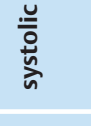 & 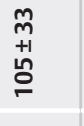 & $\stackrel{\circ}{=}$ & 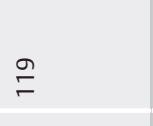 & $\Omega$ & 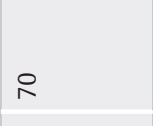 & $\varnothing$ & $\begin{array}{l}\stackrel{ \pm}{ \pm} \\
+1 \\
\infty \\
\infty\end{array}$ & \\
\hline \multicolumn{2}{|c|}{ 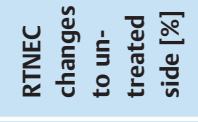 } & 仓̊ & $\begin{array}{l}\infty \\
\stackrel{\infty}{\infty} \\
\stackrel{1}{i}\end{array}$ & $\stackrel{\varphi}{\dot{P}}$ & के & $\stackrel{n}{i}$ & $\stackrel{\infty}{\stackrel{\infty}{\sim}}$ & $\stackrel{\stackrel{\circ}{+}}{+}$ & 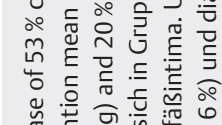 \\
\hline \multicolumn{2}{|c|}{ 崖营 } & $\begin{array}{l}\stackrel{N}{m} \\
+1 \\
0 \\
\stackrel{n}{n}\end{array}$ & 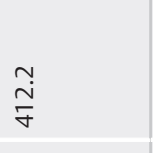 & $\begin{array}{c}\text { Õ } \\
\text { Dे }\end{array}$ & $\begin{array}{l}\infty \\
\dot{\varphi} \\
m\end{array}$ & 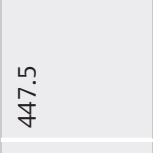 & 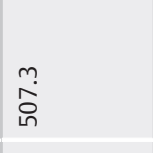 & 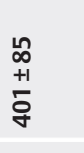 & 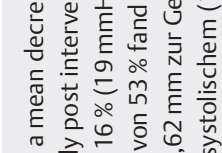 \\
\hline \multicolumn{2}{|c|}{ 㞾壱 } & 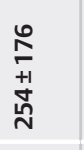 & ঙें & $\underset{\stackrel{L}{\sim}}{\stackrel{L}{N}}$ & $\begin{array}{c}0 \\
\infty \\
0 \\
0\end{array}$ & $\stackrel{d}{\sigma}$ & 守 & 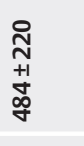 & 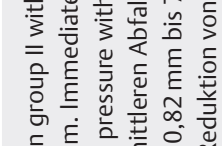 \\
\hline \multicolumn{2}{|c|}{ 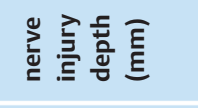 } & $\bar{m}$ & 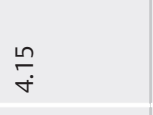 & 0 & 0 & $\underset{\sim}{\tilde{N}}$ & $\stackrel{\hat{0}}{-}$ & $\stackrel{\bullet}{-}$ & 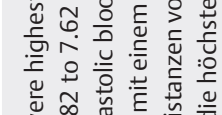 \\
\hline \multicolumn{2}{|c|}{ 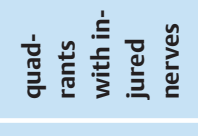 } & - & $\sim$ & 0 & 0 & - & $N$ & - & 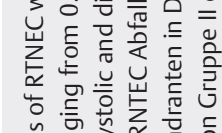 \\
\hline \multicolumn{2}{|c|}{ 芯む总孪 } & - & $\sim$ & 0 & 0 & - & $\sim$ & - & 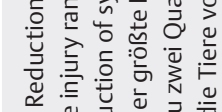 \\
\hline \multicolumn{2}{|c|}{ 㝘䒠 } & $\stackrel{\infty}{i}$ & $m$ & $m$ & $m$ & $m$ & $\sim$ & $\stackrel{\infty}{\sim}$ & 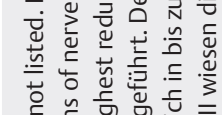 \\
\hline \multicolumn{2}{|c|}{ 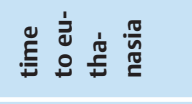 } & 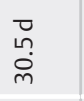 & $\stackrel{\nabla}{\Sigma}$ & స & $\stackrel{\infty}{N}$ & ত̃ & ত̃ & $\stackrel{\infty}{\sim}$ & 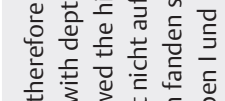 \\
\hline \multicolumn{2}{|l|}{ 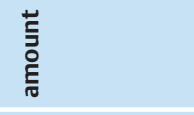 } & & $\bar{E}$ & $\bar{E}$ & $\stackrel{\bar{E}}{\circ}$ & $\bar{E}$ & $\bar{E}$ & & 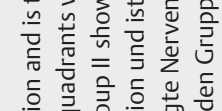 \\
\hline \multicolumn{2}{|l|}{ 苞莣 } & & 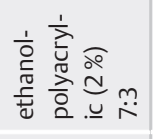 & 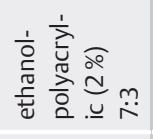 & 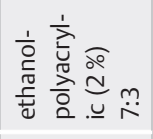 & 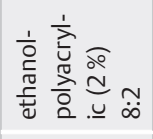 & 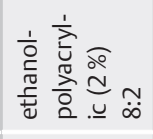 & & 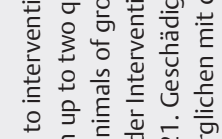 \\
\hline \multirow{2}{*}{\multicolumn{2}{|c|}{ 寅 $\overline{\widetilde{\pi}}$}} & 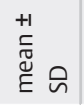 & $=$ & $\simeq$ & $\Xi$ & $\stackrel{\llcorner}{\llcorner}$ & $\stackrel{\bullet}{ }$ & 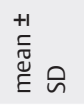 & 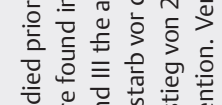 \\
\hline & & & $\begin{array}{l}\text { 三 } \\
\text { 亏े } \\
\text { 흔 }\end{array}$ & & & & & & 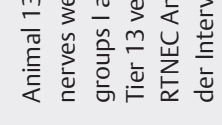 \\
\hline
\end{tabular}




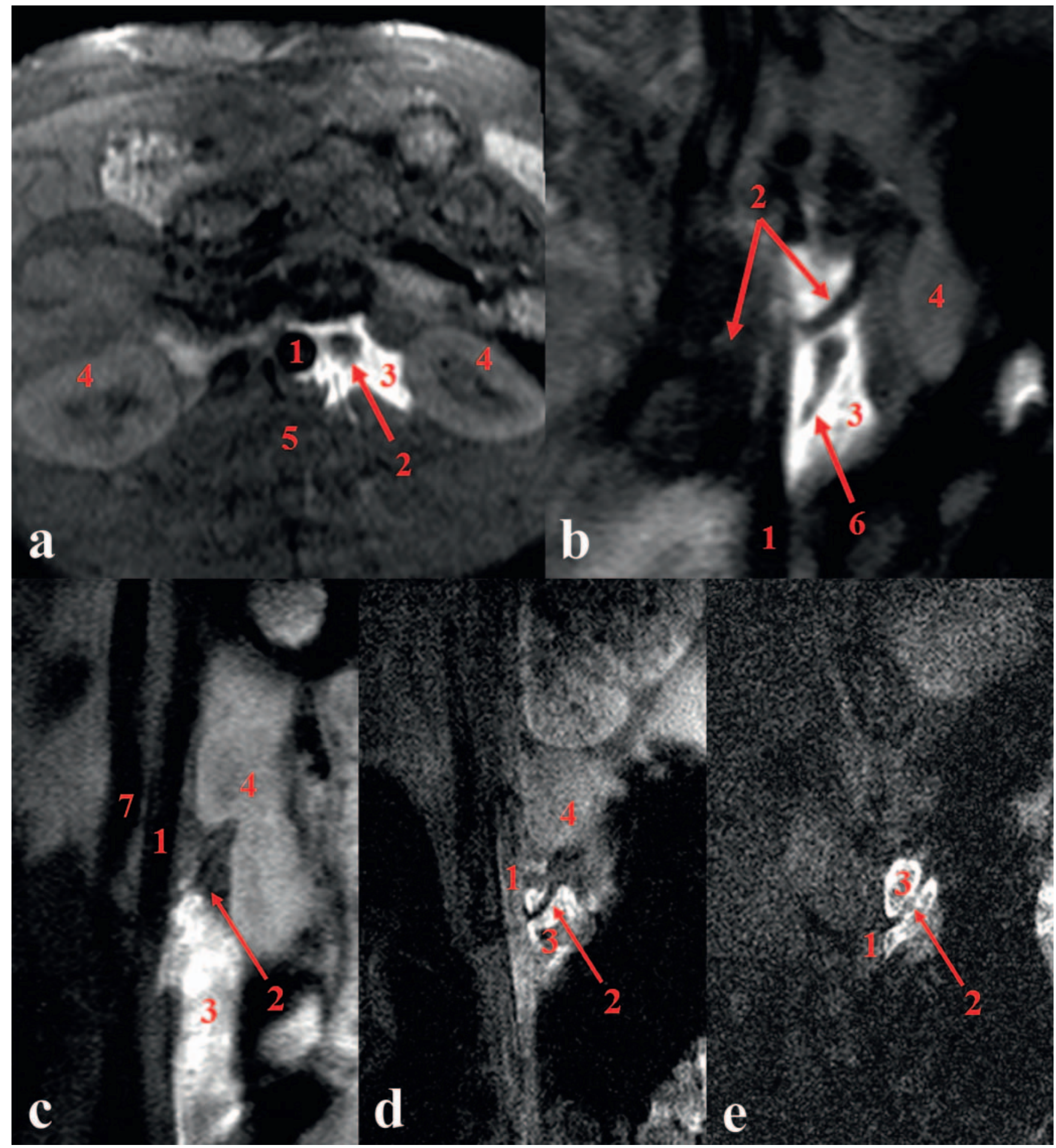

- Fig. 1 Postinterventional T1w fat-saturated TSE sequences for documentation of injectant distribution. a, b Pig 1 axial and coronal, c Pig 2 with $5 \mathrm{ml} 96 \%$ ethanol, d Pig 15 with $10 \mathrm{ml}$ ethanol/polyacrylic ratio 8:2, e Pig 12 with $10 \mathrm{ml}$ ethanol/polyacrylic ratio 7:3. 1: Aorta, 2: renal artery, 3: injectant/ethanol, 4: kidneys, 5: spine, 6: ureter, 7: inferior vena cava. a, b Images show complete coverage of the renal artery from the origin to the hilum of the kidney. No ureteral sclerosis or hydronephrosis was found in the macroscopic examination. c In pig 2 injectant distribution extends to the pelvic region. $\mathbf{d}$, e In pigs 15 and 12 the injectant stays close to the renal artery displaying a "chewing gum-like" consistency.

- Abb. 1 Postinterventionelle fettgesättigte T1-gewichtete TSE-Sequenzen zur Darstellung der Injektatverteilung. a, b Schwein 1 axial und koronal, c Schwein 2 mit $5 \mathrm{ml} 96 \%$-Ethanol, d Schwein 15 mit $10 \mathrm{ml}$ Ethanol/Polyacryl Ratio 8:2, e Schwein 12 mit $10 \mathrm{ml}$ Ethanol/Polyacryl Ratio 7:3. 1 =Aorta; 2 =A. renalis; 3 =Injektat/Ethanol; 4 = Nieren; 5 = Wirbelsäule; 6 = Ureter; 7 =Vena cava inferior. a, b Vollständige Umspülung der A. renalis durch das Injektat vom Ostium bis zum Nierenhilus. In der makroskopischen Untersuchung fanden sich weder eine Uretersklerose noch eine Hydronephrose. c In Schwein 2 zeigt sich eine Injektverteilung bis in die Beckenregion. d, e Schweine 15 und 12: Das Injektat verbleibt nahe der Nierenarterie und weist morphologisch eine „Kaugummi-ähnliche“ Konsistenz auf. 
tervention, rated as a major AE. Accidental aortic puncture occurred in pig 16 without further sequelae and was rated as a minor $\mathrm{AE}$.

\section{Macroscopic and histopathologic assessment}

Apart from the aforementioned changes of the renal capsule or ureter stricture-related hydronephrosis, other significant macroscopic changes of the periarterial tissue were not found. Pathologic changes of the renal arteries such as stenosis, aneurysm or perforations were not observed at all. For histopathological assessment, approximately 1500 probes were analyzed. Signs of nerve degeneration were found in all three treatment groups in 7 of 15 (47\%) (group I: 1 of 6, group II: 3 of 4 and group III: 3 of 6 ) animals solely on the treated side. In these 7 pigs a total of 86 nerve fascicles were identified of which 44 were normal and 42 (49\%) injured. The severity of nerve injury such as peri- and epineural damage (healing fibrosis and inflammation with decreased demarcation of the neural structures to the adjacent tissue) as well as endoneural harm (vacuolization, pyknotic nuclei and digestion chambers) ranged from grade 1 to 3 . ( $\triangleright$ Fig. 2 ) The depths achieved ranged from $0.82 \mathrm{~mm}$ (pig 4, group I) to $7.62 \mathrm{~mm}$ (pig 8, group II). (• Fig. 3)

In correspondence to the damage found in the H\&E and EvG stains, less S-100 protein was stained in the immunostains of the damaged fascicles as a result of rarefication of the Schwann cells. Signs of injury were already found two hours after the intervention (pig 4) and lasted up to 42 days to the time of euthanasia.

Within the $5 \mathrm{ml}$ group (pigs $1-6, \mathrm{p}=0.6$ ), no significant difference in the comparison of intact nerves per slide on the treated and untreated side was found. However, in the $10 \mathrm{ml}$ groups (group II and III) the number of intact nerves was significantly lower on the treated side $(p=0.021)$ with the exception of one animal in group III, which showed a higher number of intact nerves on the treated side ( $\triangleright$ Fig. 4 ).

Damage to the periarterial tissue ranged from grade 0 to 4 and was observed in animals of all three groups. While damaged periarterial tissue was found in up to 4 quadrants, injured nerve fascicles were found in up to 2 quadrants only. Endothelial cell loss, media damage or mural thrombus was not observed in any of the animals.

\section{RTNEC and blood pressure measurements}

For RTNEC measurements animals 3 and 4 were excluded due to the short time span between intervention and euthanasia. In group I an RTNEC decrease on the treated side was found in two animals $(-39.8 \%,-34 \%)$. In the other two animals (pigs 2 and 6$)$ the RTNEC on the treated side was higher by $12.3 \%$ and $8.7 \%$. The mean decrease in all 4 pigs was $-19.5 \%$. In group II the mean decrease was $-53 \%$ with a drop in the RTNEC on the treated side in all 4 animals (range $-44 \%$ to $-90 \%$ ). In group III only two animals showed an RTNEC decrease on the treated side with $-7.5 \%$ and $-28.6 \%$. The overall change was an increase of $+21 \%$ for the treated side.

There was no significant difference in the systolic and diastolic BP at baseline and at the 4-week follow-up, as expected in a unilateral treatment approach.

\section{Discussion}

Renal denervation by catheter-based RFA for the treatment of therapy-resistant hypertension has followed a winding path over the last decade. After a major setback due to the publication of the HTN-3 trial [16], the results of recent studies have rehabilitated the method somehow $[2,4,17]$. Yet, in the meta-analysis on the short- and long-term effects of RFA-RDN, Coppolino et al. stated that RFA-RDN had no tangible effects on blood pressure control in summary [18]. In fact, individual responses are highly variable, including a relevant portion of non-responders related to the anatomical and procedural limitations faced by RFA [7].

Percutaneous chemical RDN with ethanol seems promising since the drawbacks of endovascular RFA may be overcome. The advantages of ethanol lie in its high neurolytic potential, its good solubility with fast and extensive distribution within the tissue and its good availability while being inexpensive.

Previous pre-clinical and clinical studies achieved promising results with regard to the efficacy and safety of this approach $[8,11]$. Yet, a detailed histologic analysis of the ethanol-induced changes to the neural structures as well as to the renal artery and its surrounding tissue is still missing. However, a profound understanding of the induced and inducible changes is important for various reasons: One, to make the method comparable to other techniques - using RFA or chemical approaches; second, to recognize specific advantages and disadvantages of the method, therefore making it possible to optimize the technique, especially leading up to further clinical studies.

In this study, we achieved successful ethanol-mediated cRDN with RTNEC drops of up to $90 \%$. The observed reductions are in line with those reported in other studies in animals and humans after percutaneous extra-arterial and transarterial approaches [1, 10, 19-21]. Similar results for CRDN with Vincristine were achieved by Stefanadis et al. and Freyhardt et al. but with different approaches and different amounts of vincristine used, indicating that a direct dose transfer between differing experimental ways of substance administration and animal models is complicated [20].

A mean decrease of $53 \%$ for the $10 \mathrm{ml}$ ethanol group and better distribution scores compared to a drop of $20 \%$ for the $5 \mathrm{ml}$ ethanol group indicate a dose-dependent effect. This may be explained by a better periarterial distribution with better coverage of the proximal and distal segments of the renal artery. Indeed, correlation analysis revealed a positive association (Kendalls Taub: 0.495 ) between the ethanol amount and the circumferential effect (number of quadrants with injured nerves) as well as the degree of nerve injury (correlation coefficient: 0.353 ). Although the statistical significance is limited due to the small cohort, it may well be assumed that a further increase of the ethanol amount might have led to an even more pronounced effect on the sympathetic nerves. Yet, with regard to an increasing risk of affection of adjacent sensitive structures, the limit of $10 \mathrm{ml}$ was not exceeded. Changing the ratio of the injectant with an increase of the ethanol concentration (e. g. ethanol:carbostesin:CA 8:1:1 instead of 7:2:1, or even 9:1 ethanol:CA with sufficient i.v. analgosedation) could be an option for increasing the neurolytic effect further.

Distribution of the ethanol into the periarterial tissue away from the vessel is supposed to be responsible for the loss of effica- 


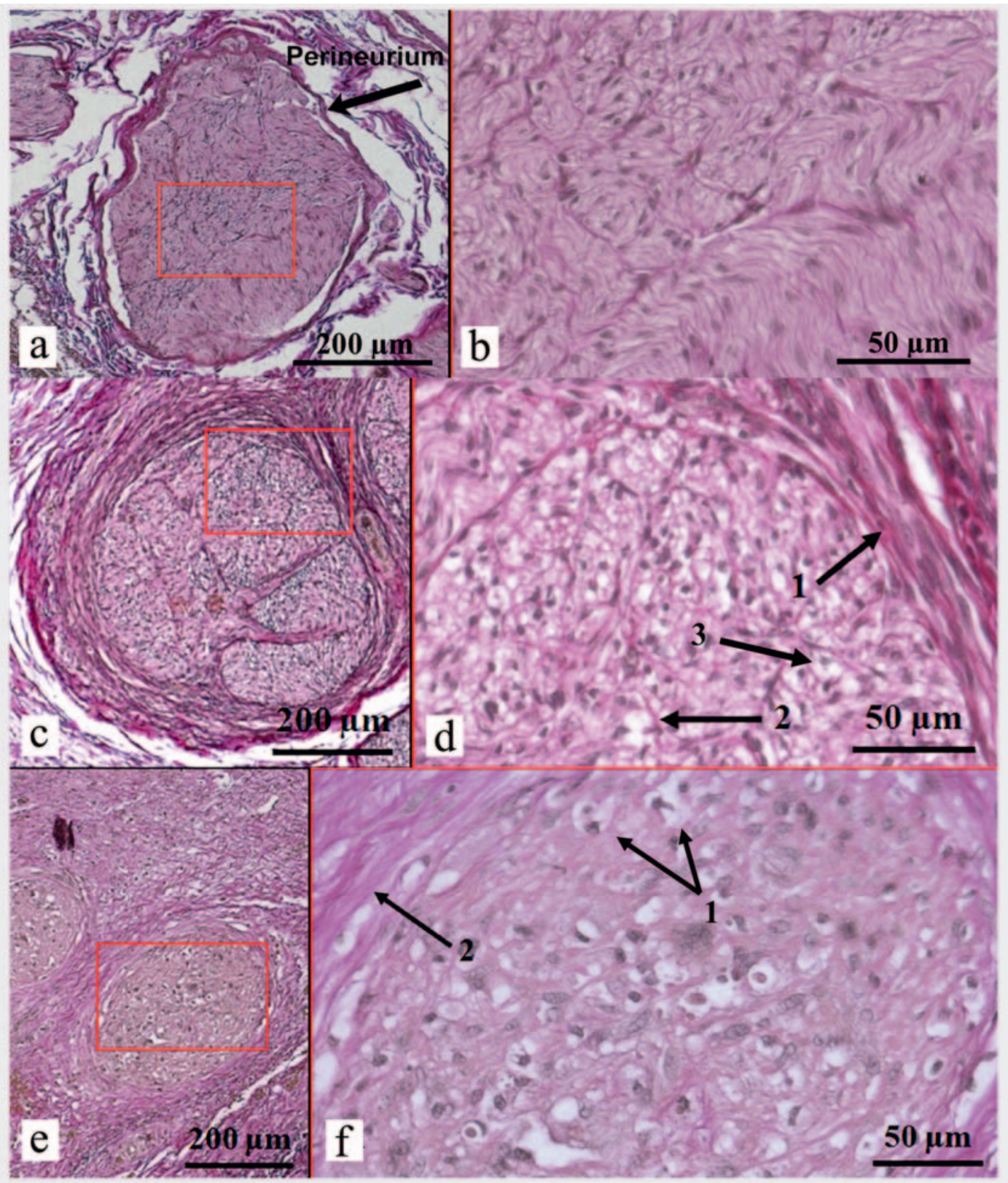

- Fig. 2 Histologic samples of periarterial nerves and surrounding connective tissue and varying degrees of injury. EvG-stain, 5-fold (left) and 20fold (right) magnification. a, b Intact nerve fascicle of an untreated control (grade 0 ) with a thin perineurium and normal appearance of the axonal structures. c, d Nerve injury grade 2. Perineural fibrosis with diffuse thickening of the perineurium c, d1. An increase in red stained collagen fibers within the endoneurium due to fibrosis is seen. Mild vacuolization $\mathbf{d} \mathbf{2}$ and rare digestion chambers $\mathbf{d} \mathbf{3}$ occur. e, $\mathbf{f}$ Nerve injury grade $\mathbf{3}$. Comparable changes to grade 2, yet, signs of nerve injury are more distinct and frequent. With increasing damage to the nerve, the differentiation between fascicle and connective tissue gets lost: the perineum and the adjacent connective tissue are merging, a clear distinction is no longer possible e. Red fibers found in the perineurium can be interpreted as a progeny of connective tissue due to moderate inflammation and fibrosis $\mathbf{f} \mathbf{2}$. The nerve fascicle is intensely interstratified with vacuoles. The amount of digestion chambers $\mathbf{f} 1$ and pyknotic nuclei is increased in comparison to nerve injury grade 2 . Furthermore, endoneural swelling can be observed.

- Abb. 2 Histologische Präparate periarterieller Nerven und des angrenzenden Bindegewebes mit unterschiedlicher Ausprägung der Schädigung. EvG-Färbung, 5-fache (links) sowie 20-fache (rechts) Vergrößerung. a, b Intakter Nervenfaszikel aus der unbehandelten Kontrollgruppe (Grad 0) mit schlankem Perineurium und normalem Erscheinungsbild der axonalen Strukturen. c, d Nervenschädigung Grad 2. Perineurale Fibrose mit diffuser Verdickung des Perineuriums sowie verminderter Abgrenzbarkeit zum angrenzenden Bindegewebe c, d1. Das Endoneurium zeigt eine geringe Vakuolenbildung d2, vereinzelte Digestionskammern d3 und pyknotische Nuklei. e, f Nervenschädigung Grad 3. Zur Nervenschädigung Grad 2 vergleichbare Schädigungsmerkmale, jedoch in häufigerer und stärkerer Ausprägung. Mit zunehmendem Schädigungsgrad nimmt die Differenzierbarkeit zwischen Faszikel und angrenzendem Bindegewebe ab. Perineum und angrenzendes Bindegewebe gehen unscharf ineinander über ohne klare Abgrenzbarkeit e. Im Perineurium abzugrenzende rote Fasern sind als Korrelat einer zunehmenden Bindegewebsvermehrung im Rahmen einer moderaten Entzündungsreaktion und Fibrosierung zu werten. Die Anzahl an Digestionskammern und pyknotischen Nuklei ist gegenüber Grad 2 erhöht. Des Weiteren ist eine endoneurale Schwellung sichtbar. 


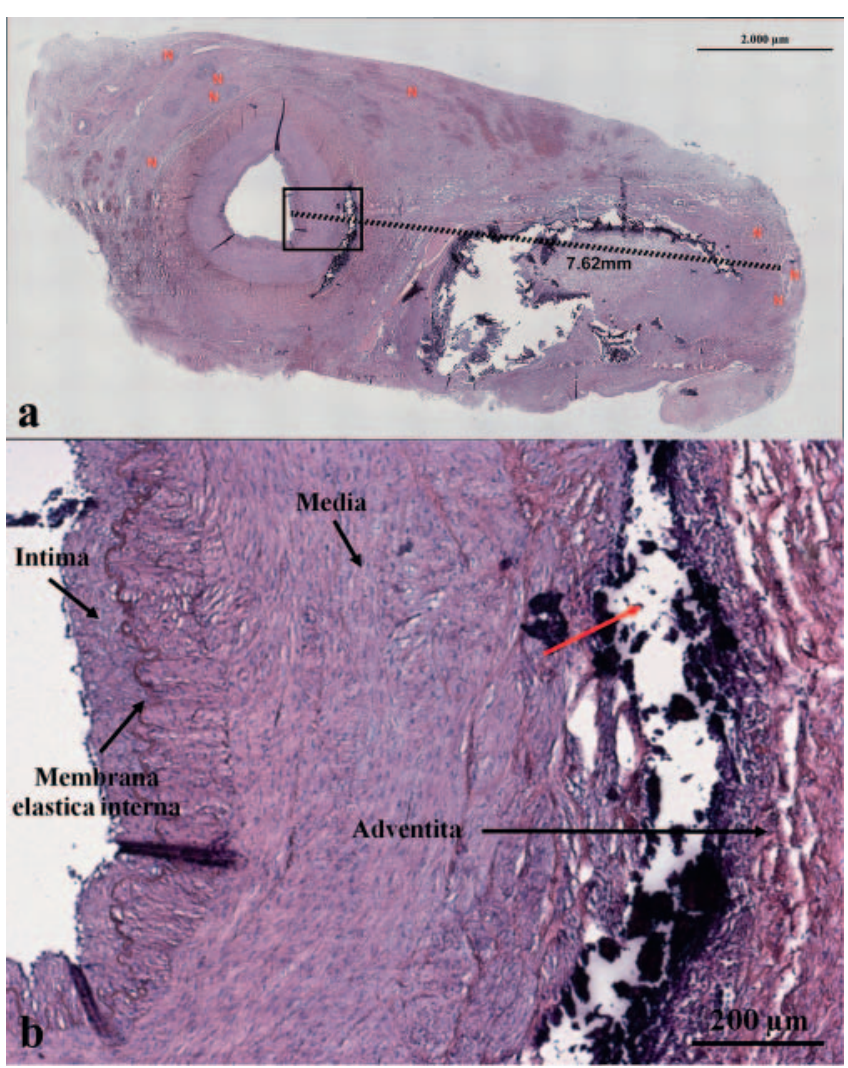

- Fig. 3 a, b Panorama view (HE stain) of renal artery and adjacent tissue containing periarterial nerves $(\mathrm{N})$ of the treated side in pig 8 . Damaged nerves are found at a distance of up to $7.6 \mathrm{~mm}$ from the arterial lumen. $\mathbf{b} 5 \times$ detail enlargement (HE stain) of the arterial wall and its adjacent tissue. Dystrophic calcification corresponding to grade 4 damage (red arrow) is located between media and adventitia. The inner layers are intact.

- Abb. 3 a Übersichtsdarstellung (HE-Färbung) der A. renalis der behandelten Seite von Schwein 8 mit angrenzendem Bindegewebe und darin enthaltenen Nervenfaszikeln (N). Geschädigte Faszikel finden sich in einer Distanz von bis zu 7,6 cm vom arteriellen Lumen. b 5-fache Vergrößerung (HE-Färbung) von arterieller Gefäßwand und angrenzendem Gewebe. Dystrophe Kalzifizierung zwischen Media und Adventitia (Grad-4-Schädigung). Die innere Schichtung der Media ist erhalten.

cy over time. Increasing the injectant's viscosity by adding polyacrylic might have led to better efficacy due to an extension of the impact time. However, in contrast to group II, the RTNEC decrease was not observed in group III. Considering that RFA treatment of the renal artery branches showed significantly better results compared to treatment of just the main renal artery, a possible explanation may be that the viscosity of the ethanol-polyacrylic mixture was too high to sufficiently "flush" the distal segments of the renal artery $[22,23]$. In fact, post-interventional MRI images showed less widespread distribution of the injectant with a "chewing gum-like" formation at the location of injection close to the orifice of the renal artery.

A dose-dependent effect was also described by Fischell et al. with varying RTNEC reductions as a function of the applied ethanol amount [19]. Interestingly, Fischell et al. achieved a compar- able RTNEC decrease with 12 to 47 times lower amounts of ethanol compared to our study as well as compared to Firouzni et al. in sheep [21]. Since Fischell et al. injected pure ethanol instead of an ethanol-contrast-agent-local-anesthetic mixture, a possible explanation may be a loss of concentration and therefore efficacy. In particular, this may also be assumed for group III with ethanolpolyacrylic ratios of $70 \%: 30 \%$ and $80 \% / 20 \%$, respectively.

For a successful RDN, a circumferential lesion pattern at an adequate depth is crucial to sufficiently address and damage the periarterial nerves [24, 25]. In the presented study, the number of quadrants with injured nerves was higher for the $10 \mathrm{ml}$ cohorts, supporting the assumption of better arterial and nerve coverage with larger injected volumes. While MRI images demonstrated good periarterial distribution of the injectant with corresponding histologic changes of the periarterial soft tissues in up to four quadrants, neural damage was limited to two quadrants only.

The following reasons may explain this result. Sequential preparation of the tissue samples with mean intervals of 1.8 $2.5 \mathrm{~mm}$ might have led to missing injured nerves for histopathologic assessment. Sakaoka et al. recently stated that fine sectioning with $500 \mu \mathrm{m}$ intervals would provide more realistic information about histopathologic changes after RFA than "conventional” preparation intervals [26]. This suggestion may be transferred to cRDN as well. Furthermore, treatment-related histopathologic changes may be underestimated or even missed due to a complete loss of nerve distinguishability from adjacent structures on the one hand and regeneration and restoration processes over time on the other hand. Observing a discrepancy between nerval function (based on TH immunostaining) and histopathological appearance, Bertog et al. suggested that damaged nerves may recover morphologically in three months without full functional recuperation [27]. This may explain the discrepancy of reduced nerve function expressed by an RTNEC decrease without coexisting histopathologic changes in some of the animals in our study.

Interestingly, the periarterial distribution pattern of the applied ethanol-contrast-agent mixture with partial or complete coverage of the renal artery did not influence the effectiveness of the CRDN in the clinical setting [12].

With reported nerve structures at distances of up to $7 \mathrm{~mm}$ from the arterial lumen in human autopsies, depths of nerve injury may be a limiting factor for the effectiveness of RFA RDN since reported nerve injury depths of RFA probes were limited to a maximum of $4 \mathrm{~mm}[28,29]$. Recent clinical studies are reporting successful RDN with a significant decrease in office and ambulatory blood pressures (SPYRAL-OFF-MED and SPYRAL-ON MED) $[2,4]$. This seems controversial with respect to the data provided by preclinical studies that feature even smaller penetration depths for the latest generation of RFA probes with $2.15 \pm 0.02 \mathrm{~mm}$ for the Symplicity Spyral- and $2.32 \pm 0.02 \mathrm{~mm}$ for the latest EnligHTN-catheter [29]. On the contrary, Sakaoka et al. recently reported deeper penetration depths for the Symplicity SpyralCatheter in porcines with a maximum of $6.5 \mathrm{~mm}$ [26].

With injured nerves at distances of up to $7.6 \mathrm{~mm}$ from the arterial lumen in this study, the percutaneous approach showed effects on nerves that are out of reach for some of the current RFA probes. This result is comparable to earlier studies using percutaneous vincristine injection as well as to a report of Bertog et 


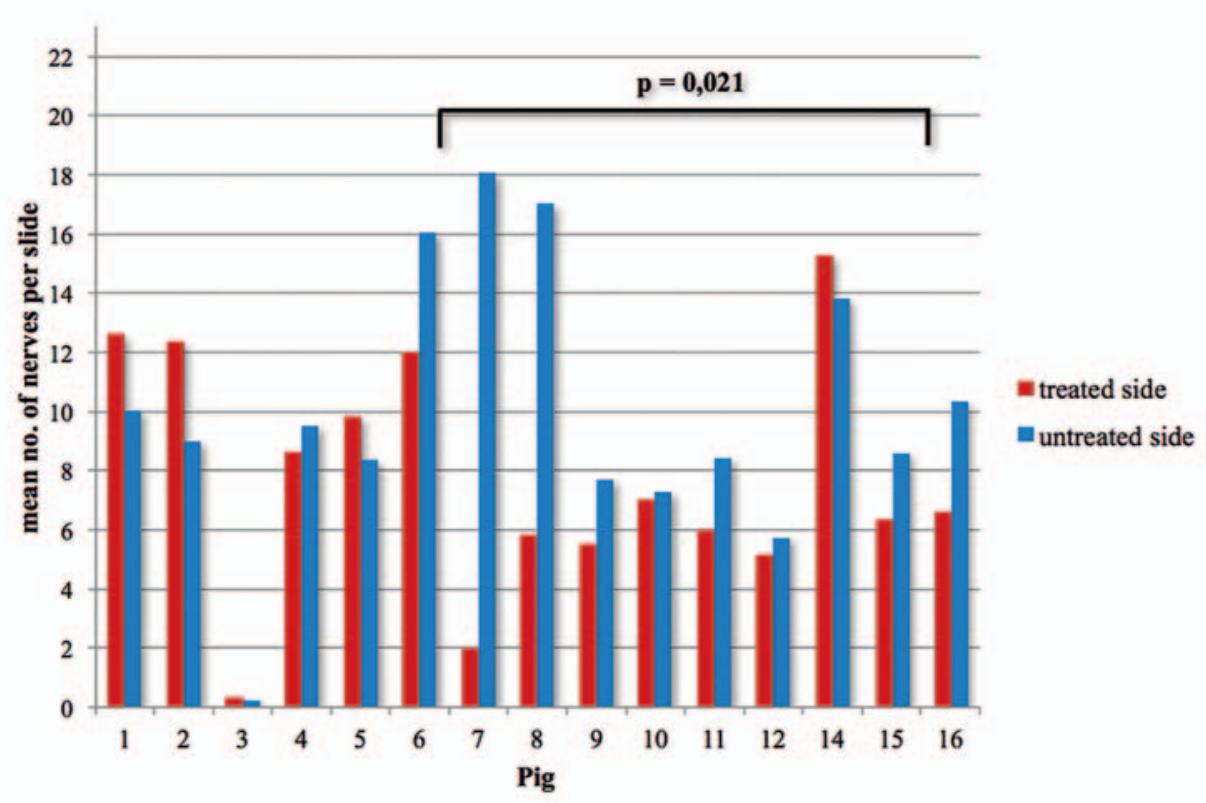

- Fig. 4 Comparison of mean number of nerves per histologic slide on the treated and untreated side. In areas of severe damage to the connective tissue, heavily damaged or completely destroyed nerves may not be recognized as nerves anymore. In these cases assessment of efficacy is possible by comparison of the nerve density (number of intact nerve fascicles per slide) of the treated and untreated side. In groups II and III ( $10 \mathrm{ml}$ ethanol) the mean number of nerves was significantly $(p<0.5)$ lower on the treated side. In group I no significant difference was found.

- Abb.4 Vergleich der durchschnittlichen Nervenanzahl pro histologischem Schnitt von behandelter und unbehandelter Seite. In Arealen mit ausgeprägter Bindegewebsschädigung können stark geschädigte oder komplett zerstörte Nerven nicht erkannt oder übersehen werden. Hier gelingt der Nachweis einer Schädigung durch den Vergleich der mittleren Nervendichte (Anzahl intakter Nervenfaszikel pro Schnitt) von behandelter und unbehandelter Seite. In den Gruppen II und III (10 mI Ethanol) zeigte sich die Zahl der intakten Nerven als signifikant vermindert. In Gruppe I konnte kein signifikanter Unterschied dargestellt werden.

al. with maximum tissue injury depths of $8.2 \pm 2.2 \mathrm{~mm}$ after administration of $0.6 \mathrm{ml}$ ethanol via injection catheter being achieved [20,27]. The observed nerve damage ranged from grades 1 to 3 . With a mean grade of 1.3 for the $10 \mathrm{ml}$ group, our results are lower compared to the mean scores of 1.5 to 2.4 reported by Bertog et al. and 2.7 with the use of vincristine reported by Freyhardt et al. [20, 27]. Again, this may be explained by different ethanol concentrations, since Bertog et al. injected pure ethanol into the periarterial space using the aforementioned Peregrine catheter [27]. Another explanation might be the difference in the neurotoxic potential of ethanol and vincristine.

Apart from one animal, no treatment-related major adverse event occurred in the presented study. Considering the observed hydronephrosis in this one pig, we have to add that the distance between the ostium of the renal artery and the kidney and ureter is larger in adult humans compared to the juvenile pigs treated in this study. Therefore, affection by the injectant seems less likely $[11,12]$. In addition, unfavorable injectant distribution might be avoided by appropriate positioning of the patient. Since the longest observation period was 31 days, this study can only provide data on the short-term safety and efficacy. With regard to medium- and long-term outcome, future studies need to be conducted.

\section{Limitations}

RTNEC values are difficult to measure and show a broad statistical variance with standard deviations as high as the mean value even in untreated animals [30]. Slight differences in the experimental setting, e.g. depth of anesthesia and different stress levels due to fixation or pain during the intervention, may lead to distinct changes in hormone concentration [30]. This may explain the higher RTNEC values on the treated side in some of the pigs and simulate treatment-related changes. An assessment of NE synthesis by enzyme histochemical analysis of $\mathrm{TH}$ activity was not performed since formalin-fixed specimens were used. However, immunostains against S-100 in combination with H\&E and EvG stains provided clear results.

\section{Conclusion}

Image-guided percutaneous periarterial ethanol injection has been shown to be effective for CRDN in pigs with observed nerve injury depths beyond those of current RFA probes. Changes in RTNEC concentration and histopathology vary as a function of the amount, concentration and viscosity of the injectant used. The method appears to be safe in the short-term follow-up. The preclinical data of this study underline the need for further optimization of the method in order to achieve more homogeneous 
and reproducible histologic outcomes as well as longer observation intervals in order to assess medium- and long-term outcome.

\section{CLINICAL RELEVANCE OF THE STUDY}

- Renal denervation by percutaneous periarterial ethanol injection was performed safely and effectively in a small group of patients in recent studies.

A detailed analysis of the induced histologic effects and thus comparability of the percutaneous approach to other methods of renal denervation are missing to date.

- Histologic changes after percutaneous periarterial ethanol injection for renal denervation are comparable to those of other approaches.

- Since the percutaneous approach is less prone to anatomical and procedural limitations compared to RFA or other endovascular procedures, it could become an alternative to these techniques. However, further optimization of the method needs to be established.

\section{Ethical approval statement}

All applicable institutional and national guidelines for the care and use of animals were followed.

\section{Informed consent statement}

Does not apply.

\section{Conflict of Interest}

The authors declare that they have no conflict of interest.

\section{References}

[1] Krum H, Schlaich M, Whitbourn R et al. Catheter-based renal sympathetic denervation for resistant hypertension: a multicentre safety and proof-ofprinciple cohort study. Lancet 2009; 373: 1275-1281

[2] Townsend RR, Mahfoud F, Kandzari DE et al. Catheter-based renal denervation in patients with uncontrolled hypertension in the absence of antihypertensive medications (SPYRAL HTN-OFF MED): a randomised, shamcontrolled, proof-of-concept trial. Lancet 2017; 390: 2160-2170

[3] Azizi M, Schmieder RE, Mahfoud F et al. Endovascular ultrasound renal denervation to treat hypertension (RADIANCE-HTN SOLO): a multicentre, international, single-blind, randomised, sham-controlled trial. Lancet 2018; 391: 2335-2345

[4] Kandzari DE, Bohm M, Mahfoud F et al. Effect of renal denervation on blood pressure in the presence of antihypertensive drugs: 6-month efficacy and safety results from the SPYRAL HTN-ON MED proof-of-concept randomised trial. Lancet 2018; 391: 2346-2355

[5] Schonherr E, Rehwald R, Nasseri P et al. Retrospective morphometric study of the suitability of renal arteries for renal denervation according to the Symplicity HTN2 trial criteria. BMJ Open 2016; 6: e009351

[6] Versaci F, Trivisonno A, Olivieri C et al. Late renal artery stenosis after renal denervation: is it the tip of the iceberg? International journal of cardiology 2014; 172: e507-e508
[7] Pappaccogli M, Covella M, Berra E et al. Effectiveness of Renal Denervation in Resistant Hypertension: A Meta-Analysis of 11 Controlled Studies. High Blood Press Cardiovasc Prev 2018. doi:10.1007/s40292-018-0260-5

[8] Streitparth F, Walter A, Stolzenburg N et al. MR-guided Periarterial Ethanol Injection for Renal Sympathetic Denervation: A Feasibility Study in Pigs. Cardiovascular and interventional radiology 2013. doi:10.1007| s00270-013-0570-x

[9] Fischell TA, Fischell DR, Ghazarossian VE et al. Next generation renal denervation: chemical "perivascular" renal denervation with alcohol using a novel drug infusion catheter. Cardiovasc Revasc Med 2015. doi:10.1016/j.carrev.2015.04.008

[10] Freyhardt P, Schutze J, Donners R et al. Renal Denervation by Transaortic Periarterial Ethanol Injection: An Experimental Study in Porcines. Cardiovascular and interventional radiology 2018; 41: 1943-1951

[11] Streitparth F, Gebauer B, Nickel P et al. Percutaneous computer tomography-guided ethanol sympathicolysis for the treatment of resistant arterial hypertension. Cardiovascular and interventional radiology 2014; 37: 513-518

[12] Ricke J, Seidensticker M, Becker S et al. Renal Sympathetic Denervation by CT-Guided Ethanol Injection: A Phase II Pilot Trial of a Novel Technique. Cardiovascular and interventional radiology 2016; 39: 251-260

[13] Swindle MM. Comparative anatomy and physiology of the pig. Scand J Lab Anim Sci Suppl 1998; 25: 1-10

[14] Sakakura K, Ladich E, Edelman ER et al. Methodological standardization for the pre-clinical evaluation of renal sympathetic denervation. JACC Cardiovascular interventions 2014; 7: 1184-1193

[15] Bauch H], Kelsch U, Hauss WH. A single, rapid, selective and quantitative determination of adrenaline and noradrenaline in the plasma by a combination of solvent extraction, HPLC separation and electrochemical detection. Journal of clinical chemistry and clinical biochemistry Zeitschrift fur klinische Chemie und klinische Biochemie 1986; 24: 651-658

[16] Bhatt DL, Kandzari DE, O’Neill WW et al. A Controlled Trial of Renal Denervation for Resistant Hypertension. The New England journal of medicine 2014. doi:10.1056/NEJMoa1402670

[17] Azizi M, Sapoval M, Gosse P et al. Optimum and stepped care standardised antihypertensive treatment with or without renal denervation for resistant hypertension (DENERHTN): a multicentre, open-label, randomised controlled trial. Lancet 2015; 385: 1957-1965

[18] Coppolino G, Pisano A, Rivoli L et al. Renal denervation for resistant hypertension. Cochrane Database Syst Rev 2017; 2: CD011499

[19] Fischell TA, Vega F, Raju $N$ et al. Ethanol-mediated perivascular renal sympathetic denervation: preclinical validation of safety and efficacy in a porcine model. Eurolntervention: journal of EuroPCR in collaboration with the Working Group on Interventional Cardiology of the European Society of Cardiology 2013; 9: 140-147

[20] Freyhardt P, Donners R, Riemert A et al. Renal denervation by CT-guided periarterial injection of hyperosmolar saline, vincristine, paclitaxel and guanethidine in a pig model. Eurolntervention: journal of EuroPCR in collaboration with the Working Group on Interventional Cardiology of the European Society of Cardiology 2017; 12: e2262-e2270

[21] Firouznia K, Hosseininasab S], Amanpour S et al. Renal Sympathetic Denervation by CT-scan-Guided Periarterial Ethanol Injection in Sheep. Cardiovascular and interventional radiology 2015; 38: 977-984

[22] Fengler K, Ewen S, Hollriegel R et al. Blood Pressure Response to Main Renal Artery and Combined Main Renal Artery Plus Branch Renal Denervation in Patients With Resistant Hypertension. J Am Heart Assoc 2017; 6: e006196 doi:10.1161/JAHA.117.006196

[23] Pekarskiy SE, Baev AE, Mordovin VF et al. Denervation of the distal renal arterial branches vs. conventional main renal artery treatment: a randomized controlled trial for treatment of resistant hypertension. Journal of hypertension 2017; 35: 369-375 
[24] Tzafriri AR, Mahfoud F, Keating JH et al. Innervation patterns may limit response to endovascular renal denervation. Journal of the American College of Cardiology 2014; 64: 1079-1087

[25] Tzafriri AR, Mahfoud F, Keating JH et al. Procedural and Anatomical Determinants of Multielectrode Renal Denervation Efficacy. Hypertension 2019. doi:10.1161/HYPERTENSIONAHA.119.12918: HYPERTENSIONAHA 11912918

[26] Sakaoka A, Terao H, Nakamura S et al. Accurate Depth of Radiofrequency-Induced Lesions in Renal Sympathetic Denervation Based on a Fine Histological Sectioning Approach in a Porcine Model. Circulation Cardiovascular interventions 2018; 11: e005779

[27] Bertog S, Fischel TA, Vega F et al. Randomised, blinded and controlled comparative study of chemical and radiofrequency-based renal denervation in a porcine model. Eurolntervention: journal of EuroPCR in colla- boration with the Working Group on Interventional Cardiology of the European Society of Cardiology 2017; 12: e1898-e1906

[28] Vink EE, Goldschmeding R, Vink A et al. Limited destruction of renal nerves after catheter-based renal denervation: results of a human case study. Nephrol Dial Transplant 2014; 29: 1608-1610

[29] Al Raisi SI, Pouliopoulos J, Barry MT et al. Evaluation of lesion and thermodynamic characteristics of Symplicity and EnligHTN renal denervation systems in a phantom renal artery model. Eurolntervention: journal of EuroPCR in collaboration with the Working Group on Interventional Cardiology of the European Society of Cardiology 2014; 10: 277-284

[30] Hannon JP, Bossone CA, Wade CE. Normal physiological values for conscious pigs used in biomedical research. Lab Anim Sci 1990; 40: 293 298 